\title{
Humid and cold periods in the last 5600 years in Arid Central Asia revealed by palynology from Issyk-Kul
}

\author{
Suzanne AG Leroy* ${ }^{1-2}$, Santiago Giralt ${ }^{3}$
}

1 Mediterranean Laboratory of Prehistory Europa-Africa, Aix Marseille Univ, CNRS, Minist Culture, LAMPEA, UMR 7269, 5 rue du Château de l'Horloge, 13094, Aix-en-Provence, France, leroy@mmsh.univ-aix.fr, suzleroy@hotmail.com 2 School of Environmental Sciences, University of Liverpool, UK 3 Institute of Earth Sciences Jaume Almera (ICTJA-CSIC), Lluís Solé i Sabarís s/n, E-08028 Barcelona, Spain, sgiralt@ictja.csic.es

* Corresponding author

\begin{abstract}
Central Asia, with its high mountains, despite its location between Europe and eastern Asia remains a data poor area. However, mountain glaciers are strongly affected by global change and have a wide-ranging impact. A new pollen record over the last 5600 years shows the extension of a dry Artemisia steppe around Lake Issyk-Kul, with a slightly wetter period from 4.5 to $2.7 \mathrm{ka}$ BP (less Ephedra). Picea schrenkiana forest growing on north-facing slopes of the northern Tien Shan Range, are exposed to Westerlies-related precipitation. The pollen record of Picea is therefore a very good marker of wetter conditions. A comparison to a nearby synchronous pollen record at a higher altitude indicates that the whole forest belt moved down, and that it was not a downwards extension of the lower forest limit only. Four cold and humid phases were evidenced over the last 5.6 ka: $5.5 \mathrm{ka}, 4.2 \mathrm{ka}$ and following centuries, $3.2 \mathrm{ka}$ and following centuries (before the end of the Bronze Age) and finally the Little Ice Age, with the latter two being more strongly expressed. These climatic changes, in agreement with other Arid Central Asia investigations, confirm the driving role of the Westerlies far inland. Human activities were more intense in the Mid and Late Bronze Age (4.5-3.2 ka) and in the last 800 years, confirmed by archaeological and historical information. Issyk-Kul and surrounding rich pastureland were most likely an important step in the ancient Silk Road.
\end{abstract}

\section{Key words}

Tien Shan, pollen, Holocene, palaeoclimate, Picea forest, Bronze Age 


\section{Introduction}

Central Asia's past environments remain poorly studied despite key location between Asia and Europe. It is a sensitive area at the easternmost limit of the Westerlies influence and with ancient population exchanges between west and east. Its high mountains, i.e. the Tien Shan or the Celestial Mountains, are responsible for the water supply of a vast area of Arid Central Asia since they constitute the main water source for large deserts and semi-deserts of Kazakhstan, Kyrgyzstan and eastern China and further away via the Syr-Darya and the Amu-Darya (Fig. 1). This mountain range, that extends about 1,900 km in an approximately E-W orientation, contains high summits such as Jengish Chokusu at 7,439 metres above sea level ( $\mathrm{m}$ asl) and accommodates several thousand glaciers covering an approximate area of about $16,400 \mathrm{~km}^{2}$ (Pieczonka and Bolch, 2015), which makes this area very sensitive to climatic change. Air temperature has steadily increased from 1879 to the present day, which has become more pronounced since the 1950s (Bolch, 2007). Glaciers are melting at a rapid rate and, for example, those located in the Zailiyskiy and Kungey Alatau mountain ridges have decreased their extend for more than 32\% between 1955 and 1999 owing to the autumn and winter temperature rise, although recent estimates have decreased these extensive losses and showed a quite complex geographical pattern (Narama et al., 2010). These glaciers have traditionally been used as the main water source since their periodic melt are providing temporarily water to downstream fields and towns that are being continuously developed despite settlements under dry climate (Kaser et al., 2010; Sorg et al., 2012; Chen et al., 2019). These glaciers also provide water to the main lakes in Central Asia, now and in the past, like Lake Balkhash (Chiba et al., 2016), Lake Aral (Boomer et al., 2009; Burr et al., 2019), Caspian Sea (Leroy et al., 2019), Lake Son Kul in Kirgizstan (Lauterbach et al., 2014; Mathis et al., 2014), Lake Kara Kul in Tajikistan (Heinecke et al., 2018) and Issyk-Kul (Giralt et al., 2001). In the northern Tien Shan, an endemic spruce forest belt forms the rather restricted forests of Kirghizstan. It is vertically squeezed between alpine meadows and steppe at lower altitudes. It is liable to elevation displacement forced by climate and its lower limit is affected by deforestation (Klinge et al., 2015). Lake Issyk-Kul, the topic of this investigation, is located at the heart of Northern Tien Shan. This lake is on the northern branch of the Silk Road, main trade route between East and West that has been used for almost 10,000 years (Herrera and Garcia-Bertrand, 2018), until the circumnavigation of Africa was discovered. This implies that the lake shores its surroundings have been under large anthropic pressure. Maybe the best example is represented by the walnut forests, which consists almost $20 \%$ of the total fruit tree cover (Beer et al., 2008). A palynological study of the sedimentary record of four lakes located in the Fergana and Chatkal ranges showed that these forests are 2,000 years old and most probably of anthropogenic origin. Furthermore, the long- and short-term precipitation fluctuations have had a significant impact on these ancient civilizations (Cai et al., 2017).

A sediment core was taken in Lake Issyk-Kul (henceforward Issyk-Kul as kul means lake), in order to reconstruct its past vegetation (with a special focus on 
Picea), land-use and past regional climates over the last millennia (Fig. 1). This contributes to the understanding of past and present mechanisms of changes in sensitive montane ecosystems and to the improvement of our preparedness to changes to come.

[insert figure 1]

\section{Setting}

\subsection{Limnology}

Issyk-Kul is located in Northern Kirgizstan and is surrounded by the high mountains of northern Tien Shan (Fig. 1) and it is located in a very active tectonic environment (Thompson et al., 2009). Its water level is currently around $1607 \mathrm{~m}$ asl, following a slow decrease by $3 \mathrm{~m}$ since 1927 due to irrigation (Kulenbekov and Merkel, 2012). However, due to increased precipitation (especially in autumn) and glacier melting since 1998, its level has slightly re-increased (Romanovsky et al., 2013; Salamat et al., 2014). It is one of the deepest (maximal depth $668 \mathrm{~m}$ ) and largest $\left(6,236 \mathrm{~km}^{2}\right)$ mountain lake in the world. It is endorheic, with close to a hundred inflowing rivers. The two largest ones, the Dzhergalan and Tuip, feed the lake from the east. River Chu flowed into the west of the lake without hindrance until c. 1,200 years ago when lake levels were higher. After that, the river and the lake were connected only during restricted times through the Kutemaldy Channel (Kulenbekov and Merkel, 2012). Lake water characteristics are $\mathrm{pH} 8$, salinity $6 \mathrm{psu}$ and high dissolved oxygen concentrations of $8.9 \mathrm{mg}$ per liter (Savvaitova and Petr, 1992). Surface water temperature is usually warmer than air temperature, varying between 18 (summer) and 4 (winter) ${ }^{\circ} \mathrm{C}$ (Savvaitova and Petr, 1992). The lake name means the warm lake as its waters never freeze. The lake is meromictic.

The phytoplankton in the open lake is dominated by Botryococcus braunii (Chlorophyta), Peridinium borgei (Dinophyceae), Amphipora (Bacillariophyta) (Savvaitova and Petr, 1992; Romanovsky, 2002a).

Issyk Kul is a Ramsar wetland of globally significant biodiversity and forms part of the Issyk-Kul Biosphere Reserve (Ramsar, 2013).

\subsection{Vegetation}

The vegetation around Issyk-Kul is largely arranged in altitudinal belts (Walter and Box, 1983; Giralt et al., 2002, 2004; University of Central Asia, 2018). The western part of the lake basin is surrounded by semi-desert vegetation that is characterized by Ephedra and Amaranthaceae (Salsola, Suaeda). Dry steppe (Artemisia and Poaceae) is widespread at the bottom of the mountain slopes and along the shores of the eastern basin. These areas have been transformed by agricultural use. Hippophaë rhamnoides thickets grow along river courses. The riparian ecosystem also contains Populus, Salix and Betula. Only a very restricted deciduous belt of mostly fruit trees is present on the wetter west-facing slopes, especially in the central and southern parts of the country: Juglans, a series of Rosaceous fruit trees and pistachios. The tree belt in the drier south is dominated by Juniperus and in the wetter north by Picea schrenkiana, especially 
on northern slopes (Klinge et al., 2005). The snow spruce belt is at (1300) 20002800 (3600) $\mathrm{m}$ altitude near Issyk-Kul. Abies forests grow in the far north and west. The alpine and sub-alpine meadows and pastures (with sedges) are characterised by Poaceae and Lamiaceae amongst a rich diversity of other herbs. Specifically the altitudinal spread of the spruce forest belt has been studied in the Ketmen Mountain range (northernmost Tien Shan between Kazakhstan and China). It shows a lower limit in the north-west at $1600 \mathrm{~m}$ and in the south-east at $2600 \mathrm{~m}$ and an upper limit respectively at 1800 and $2900 \mathrm{~m}$ (Klinge et al., 2005). Hence, the elevation range of this belt is only 200 and 300 $\mathrm{m}$ respectively. In rare places, well exposed to precipitation (W and N-W slopes), the altitudinal range may exceptionally reach $900 \mathrm{~m}$.

\subsection{Climate}

The climate is continental dry and dominated by the Westerlies. The Siberian anticyclones have occasional influence on the mountains north of the lake (Aizen et al., 1997). Winds enter the Issyk-Kul basin from the west and from the east through topographic lows, they are associated with Arctic air (Podrezov et al., 2020). Local wind directions are varied due to the orographic effect but are predominantly lakeward (Shabunin and Shabunin, 2002). At Cholpon-Ata, the station close to the coring point, the winds are mainly from the North.

The climate in the lake catchment area is highly variable: from warm temperate and dry in the western part to slightly humid in the eastern part. The annual precipitation averages $250 \mathrm{~mm}$ and the annual evaporation from the surface of the lake is approximately $700 \mathrm{~mm}$ (Giralt et al., 2004).

\subsection{Archaeology and palaeoclimates}

The lake surroundings have wide archaeo-historical interest mainly as a way station along the Silk Road. Significant ruins dot the lake shores.

However human occupation dates further back with several nearby Palaeolithic sites (Romanovsky, 2002b; Herrera and Garcia-Bertrand, 2018). Archaeological sites in the region around Issyk-Kul count numerous petroglyphs and 3,000 yearold kurgans (nomadic burial mounds). The Bronze Age site of Uch Kurbu is situated on the south shore of Issyk-Kul (Luneau et al., 2020) (Fig. 1). It indicates the integration of the Kirghiz culture into the larger Andronovo one (extending from the Caspian Sea to Dzungaria). The site of Chap (some $35 \mathrm{~km} \mathrm{W-SW} \mathrm{of}$ Issyk-Kul) shows clear evidence of Bronze Age nomadism and agro-pastoralism (Motuzaite Matuzeviciute et al., 2019). The Chap II site yielded the largest crop assemblage dated to the third millennium BC between Pamir, Tien Shan and Altai Mountains, consisting of wheat and barley (Motuzaite Matuzeviciute et al., 2020). Historical remains such as early Christian monasteries and medieval cities are found too (Romanovsky, 2002b; UNESCO, 2017). A possible Timurid palace $\left(14^{\text {th }}\right.$ century $\left.A D\right)$ was submerged along the northern shores of Issyk-Kul (National Geographic, 2012).

The extension of the Tien Shan glaciers has varied, mainly linked to short- and long-term fluctuations in precipitation and temperature (Koppes et al., 2008; Chen et al., 2010; Cheng et al., 2012; Burgette et al., 2017; Chen et al., 2019). The decadal-scale climate evolution for the last 1,000 years showed that the 
Dark Age Cold Period ( AD 300 - 600) was cold and wet, while the Medieval Climate Anomaly ( AD 1,000 - 1,350) was dominated by relatively dry conditions while the Little Ice Age ( AD 1,500 - 1,850) was usually humid (Yan et al., 2009; Lan et al., 2018). These climate fluctuations were linked with changes in the precipitation due to variations in the mid-latitude cyclone activity as a result of shifts in the intensity and position of the westerly jet stream (Chen et al., 2006; Chen et al., 2010), although other authors consider that, at least for the last 160 years, they are also closely related to the North Atlantic Oscillation (NAO) index and solar activity (Yan et al., 2019).

\section{Past investigations on lacustrine sediment cores}

\subsection{In the area}

Beer and Tinner (2008) analysed the pollen, macrofossils and microcharcoals in a sediment core taken in Karakol, only 17 km north of Issyk-Kul (Fig. 1). This small lake is at a higher altitude (i.e. 2,353 $\mathrm{m}$ asl) than Issyk-Kul and is located in the snow spruce belt. The sequence, covering the last four calibrated ka (all dates are calibrated; so from now on "cal." will not be specified), allows reconstructing the vegetation history of this forest. A clear die back of spruce is recorded between 3,350 and 2,900 yr BP and is interpreted as climatic deterioration, i.e. cooling. Human influence on the vegetation seems to have started later, at $1600 \mathrm{yr}$ BP.

Slightly further afield, two Holocene records show differing information after c. 5000 years. Firstly Lake Sayram (northern Xinjiang) at $2072 \mathrm{~m}$ elevation, $280 \mathrm{~km}$ E-NE of Issyk-Kul, in an alpine meadow, has provided a pollen record covering the Holocene (Fig. 1). It shows increasing humidity over the last $5600 \mathrm{yr}$ (Jiang et al., 2013). Secondly Sonkul, the other Holocene record, this time at $3010 \mathrm{~m}$ asl and $200 \mathrm{~km}$ SW of Issyk-Kul, is in a treeless area with grasslands and its sequence shows aridification after 5000 yr ago (Mathis et al., 2014) (Fig.1). The data compilation and moisture simulations of Li et al. (2020) indicate that IssykKul belongs to the region they call northern central Asia whose climate is driven by the Westerlies, and that is characteristic by a dry early Holocene, followed, after a sharp change at $8 \mathrm{ka}$, by a wet mid-Holocene and a slightly drier Late Holocene. A colder climate seems to have set in from $4.5 \mathrm{ka}$. Immediately south of it (the southern central Asia region), the climate of the Early Holocene is humid, becoming very progressively drier. This may explain the difference between Sayram and Sonkul palaeoclimatic history.

\subsection{In the lake}

In a series of cores taken in 1997 and 2000, pollen and stable isotopes were analysed. A summary pollen diagram covering a large part of the Holocene from two combined cores (taken west and east of the lake) shows changes between wetter and drier periods (O. Grigina in Rasmussen et al., 2001). But the lack of details (low time resolution and low counts) hinders its use. Stable isotope analyses show that between 6 and $4.8 \mathrm{ka}$, a regression transforms the lake from an open lake into a close basin causing salinity increase (Rasmussen et al., 2001) and, from 4.9 ka BP onwards, a relatively stable lake (Ricketts et al., 
2001). Further palynology and stable isotope investigations on core IK00-11P (Leroy et al., pers. comm.) taken in the centre east of the lake (Fig. 1), covers from 12,750 to 3590 years and reveals a dry early Holocene lake strongly influenced by meltwaters from adjacent glaciers.

A couple of pollen diagrams, from shorter cores taken in 1998, were obtained on core IK98i-28 at $168 \mathrm{~m}$ water depth in the north of the lake (Fig. 1). The first diagram of sixteen samples spanned most of the core that was roughly estimated to cover the last 2000 years by extrapolation of the ${ }^{210} \mathrm{~Pb}$ curve (Giralt et al., 2002). It showed an Artemisia steppe with less than 5\% of Picea, and an increasing human impact upwards. A second diagram (26 samples) focused in more details on the top $46 \mathrm{~cm}$ of the same core (Giralt et al., 2004). The latter record is 1000 year-long and shows the dominance of Artemisia, a low Arboreal Pollen (AP) content, the increase of anthropic elements in the last tens of $\mathrm{cm}$, and a slight increased moisture at AD 1000-1180 and 1700-1900 (more hydrocalcite and higher Artemisia/Ephedra ratio). Picea percentages range between 2 and $11 \%$.

\subsection{In cores C142a and C087}

Core C087, the object of the present palynological investigations, has been studied previously alongside the nearby core C142a. The results of these two cores support each other. This is presented here in brief only, as full details may be found in Larrasoaña et al. (2011) and Gomez-Paccard et al. (2012). Cores

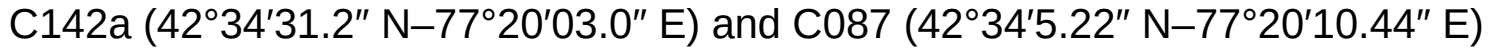
were collected in 2000 using a gravity corer at water depths of 150 and $312 \mathrm{~m}$, respectively (Fig. 1).

\section{[insert figure 2]}

Core C142a comprises a 150-cm-thick sequence of Late Holocene clays, silts and sandy silts that accumulated on a distal lobe of the deltaic system. Core C087 consists of $132 \mathrm{~cm}$ of alternating centimetre to millimetre light and dark grey clays and silty clays that are equivalent to those in the uppermost $94 \mathrm{~cm}$ of core C142a. Additionally the top $18 \mathrm{~cm}$ of core C087 are dark, organic-rich and massive silty clays (Fig. 2). The lithologies of the two cores are fairly similar and thus the two logs are well correlated by their facies (Larrasoaña et al., 2011; Gomez-Paccard et al., 2012). Core IK98i-28 shows the same massive sediment unit in the top $15 \mathrm{~cm}$ (Giralt et al., 2004).

The age-depth models of the two cores are relatively well constrained by radiocarbon dating made on pollen-enriched extracts. Seven radiocarbon dates were obtained on core $\mathrm{C} 142 \mathrm{a}$ and four on core C087 (Table 1). They were corrected by 1182 years due to reservoir effect. Core C142a covers the last 3800 years and core C087 the last 5600 years (Fig. 2) (Larrasoaña et al., 2011; Gomez-Paccard et al., 2012). Mean sedimentation rates are fairly stable. A geomagnetic palaeosecular variation curve was proposed for central Asia based on these two cores (Larrasoaña et al., 2011; Gomez-Paccard et al., 2012).

[insert Table 1] 


\section{Material and Methods}

\subsection{Palynology}

Sixty-six $5 \mathrm{~mm}$-thick samples were analyzed for palynological studies from core C087 every two centimeters, i.e. every 85 years on average. The c. $2.2 \mathrm{ml}$ samples were treated with the following method: sodium pyrophosphate, $\mathrm{HCl}$, cold $\mathrm{HF}, \mathrm{HCl}$, and finally sieving on 250 and $10 \mu \mathrm{m}$ meshes. The slides were mounted in glycerol. An estimation of the concentration was obtained by the initial addition of Lycopodium tablets to a known volume of sediment. The concentration units are in number of pollen and spores per $\mathrm{ml}$ of wet sediment. On average 525 pollen and spores were counted per sample, with a minimum of 400 terrestrial pollen grains. Due to the over-representation and abundance of Artemisia, the latter was taken out of the percentage sum. The percentage diagram was thus based on a sum of minimum 180 grains. This latter sum was also used for spores, pollen from aquatic plants, fungal spores and other nonpollen palynomorphs (NPPs). Pollen zonation was obtained by CONISS in the software psimpoll after square-root transformation (Bennett, 2007).

\subsection{Chronology}

The age-depth model of the core had been updated and recalculated based on Calib 7.10 software and the INTCAL13 curve (Stuiver et al., 2020). The new calibration has only very slightly modified the previous chronology (Table 1 ).

$$
\text { [insert figure } 3 a, b, c \text { and] }
$$

\section{Results}

Artemisia, when in the sum used for percentages, would reach around $55 \%$ of the assemblages. This dominant taxon does not show any major trend through the sequence. In the diagram described here (Fig. 3a,b,c and d and 4), Artemisia has thus been taken out of the percentage sum. A zonation is established on ten terrestrial taxa (excluding Artemisia). The samples were very rich in pollen and spores with an average concentration of 137,450 grains per $\mathrm{ml}$ of wet sediment (Fig. 4).

\section{Zone IK-1, 5600-4495 yr BP}

Picea, Ephedra, Amaranthaceae, Poaceae and Cyperaceae are abundant. Frequent occurrences of Betula, Salix and Polygonum alpinum characterise this zone. In the aquatics, the two Typha taxa are frequent. Botryococcus increases and Brigantedinium is common. Microcharcoals are abundant especially in the last part of the zone. Total concentration has proportionally low values.

\section{Zone IK-2, 4495-3290 yr BP}

Ephedra and P. alpinum decline drastically. Hippophae and Salix decrease also, but only mid-way into the zone. Asteraceae liguliflorae increase slightly. Amaranthaceae have high percentages especially in the second part of this 
zone. Microcharcoals, after a drop, re-increase and reach a maximum. Anabaena makes a small but distinctive peak at the end of this zone. Botryococcus and Brigantedinium values drop. Glomus and coprophilous spores are frequent in this zone and the following.

\section{Zone IK-3, 3290-2710 yr BP}

Picea fluctuates and reaches frequently relatively high values. Ephedra reincreases slowly. Amaranthaceae show a drastic, brief, decrease, and reincrease towards the end of this zone. A. liguliflorae are still frequent.

Cyperaceae reach a maximum. Microcharcoal values are low. Botryococcus percentages increase sudden in the middle of this zone. Brigantedinium are abundant. Concentration has proportionally low values.

\section{Zone IK-4, 2710-830 yr BP}

Ephedra picks up again and remains high till the sequence top. Amaranthaceae re-increase and return to values similar to zone IK-2. While A. liguliflorae are more irregularly present, A. tubuliflorae increase slightly. In this zone and the next, Cyperaceae have low percentages. Low values of reworked elements are observed. Botryococcus displays large peaks. Brigantedinium is abundant with a large peak at $1340 \mathrm{yr}$ BP. Fungal spores and coprophilous spores reach minimal values in the middle of this zone. Glomus and coprophilous spores decline clearly from zone IK-3 to 4 . Concentration has often very high values.

\section{Zone IK- 5, 830 yr BP - AD 2000}

In most of this zone, Picea has high percentages. Amaranthaceae are slightly less well represented than in the preceding zone. A. tubuliflorae remain relatively high. Poaceae reach maximal values. Cerealia have a few occurrences. One grain of Fagopyrum is observed. After low values, Botryococcus re-increases.

\section{Interpretation and discussion}

\subsection{Terrestrial data: past vegetation and human influence}

Overall, the changes across this 5600 yr-long sequence are not drastic. The semi-desert around Issyk-Kul may have had a slightly larger expansion in zones IK-1, 4 and 5 (Ephedra), than in zones IK-2 and 3 (Fig. 4). The sharp decline of Ephedra at $4495 \mathrm{yr}$ BP (limit of zones IK1 and 2) is reminiscent of the fall of Ephedra observed in core IK00-11P at 4000 yr BP (Leroy et al., pers. comm.). Human influence is felt especially at two levels: pollen zones IK-2 and IK-5. In zone IK-2, an opening of the ground cover is reconstructed based on high charcoal (maximum at 3745 yr BP) and high Glomus values reflecting respectively fire and erosion (in zone IK 2, carrying on into zone 3 ). The first Cerealia grains are observed as well as the start of significant coprophilous indicators (since $4010 \mathrm{yr}$ BP). This correspond to the Mid and Late Bronze Age (Fig. 4). In zone IK-5, single grains of Juglans and Fagopyrum grains and small, but significant, percentages of Rumex have been found. These two periods of human activity detected in the lake sequence fit well with the archaeological record, confirming the impact of people around the lake shores at least from $c$. 4500 years BP. 
Palaeobotanical analyses of a Bronze Age site in the Naryn Valley (Aigyrzhal-2, $110 \mathrm{~km}$ SW of Issyk-Kul) at 3830-3380 yr BP (Motuzaite Matuzeviciute et al., 2017) shows charcoal fragments of Salix/Populus and Picea. The presence of the latter indicates the intentional exploitation of this tree species, although it was growing at higher altitude than the site where it was found. Although not much is known of the end of the Bronze Age around Issyk-Kul itself, a clear change at the transition Bronze Age - Iron Age is seen with the end of the Oxus civilisation (Lhuillier, no date). North of Kirghizstan and perhaps in Kirghizstan too, the Andronovo family of cultures, i.e. Bronze Age cultures, ends around 1500 BC (Jia et al., 2017). They used horses and Bactrian camels extensively for stock breeding (Parzinger, 2008). Recent palaeogenetic analyses in Bronze Age and Iron Age sites indicate that domesticated goats were preferably introduced from the Middle East to the east via the "Inner Asian Mountain Corridor" (an area that includes in the site of Uch Kurbu on the shores Issyk-Kul) (Hermes et al., 2020) (Fig. 1). The coprophilous spore increase in core C087 during the Bronze Age may be due to the grazing of horses, camels and goats, amongst others. Links between coprophilous spore records and the presence of herbivores have been made in the Qinghai-Tibetan plateau. For example the amount of Sporormiella spores was linked to the use of yaks and other animals in the surroundings of the Ganggahai Lake since 5.7 ka ago (Huang et al., 2020). Early pastoralism was inferred from a similar coprophilous spore investigation, supported by modern samples, in the Jiangxigou2 archaeological site between 6 and 5.5 ka (Wei et al., 2020).

\subsection{The Picea peaks and climate}

Picea: Tree and pollen

Picea schrenkiana is a conifer tree sensitive to climate. Blooming was observed in the Xianjiang Tienshan between in mid-May and July (Pan et al., 2013). Its lower altitudinal belt limit is responsive to moisture availability and its upper limit to temperature (Huo et al., 2017). It grows preferably on north-facing shady mountain slopes (Wu et al., 2015). It has therefore been chosen to reconstruct some aspects of past climate in the region.

On the northern slopes of the Chinese Tian-Shan, surface samples (moss polsters, litter and topsoil) were taken in an altitudinal transect below, across and above the Picea forest belt. At the altitude of the forest (1700-2700 m), Picea pollen percentages reach up to $80 \%$ (Zhang et al., 2013). In Kirghizstan, Beer et al. (2007) have analysed six modern samples (moss polsters) in a transect around Lake Karakol (north of Issyk-Kul) and found again the values between 55 and $75 \%$ in pure Picea schrenkiana stands, and still $30 \%$ in meadows close to the lake without spruce. However, the representation of Picea pollen in lake sediment is much lower. In Lake Karakol itself, the percentages of surface sediment dramatically fall to $10 \%$. In the past 4000 years, values only up to $25 \%$ were reached (Beer and Tinner, 2008). In core 98i-18, the average is $5 \%$ (maximum $21 \%$ in one sample) while in core IK00-11P the maximum is $5 \%$. Pan et al. (2013) note that Picea schrenkiana pollen dispersal may occur on long distances. In the case of Issyk-Kul, the local northerly wind at Cholpon-Ata would be favourable to a transport of airborne pollen to the lake. Moreover several 
rivers crossing the Picea forest reach the lake a few $\mathrm{km}$ east of the coring point and are another source of pollen, this time water-transported. Thus, the C087 sequence (with a maximum of $15 \%$ Picea when Artemisia is included in the sum for percentages) allows suggesting that spruce forest might have been closer to the lake, albeit only briefly, at certain points in the Holocene.

\section{[insert figure 4]}

\section{Four periods of Picea expansion}

On figure 4, the percentage curve and the concentration curve of Picea are plotted. When both are high (>18\% - Artemisia excluded- and 1500 grains per $\mathrm{ml}$ ), the snow spruce forest is considered to be at lower altitude, thus closer to the lake. Such a situation would be favoured by a wetter climate, perhaps also colder. It occurs four times: at 5510, 4190-4100-4010, 3225-3180 yr BP and a double peak at 690 and $320-220 \mathrm{yr}$ BP.

\section{$5.5 \mathrm{ka} \mathrm{BP}$}

In Issyk-Kul, a rather isolated Picea peak occurs towards the bottom of the record at $5510 \mathrm{yr}$ BP, and may or may not be part of a longer episode. In Sonkul, a period of wetter climate (increased winter snowfall and enhanced spring thaw) has been recognised at 5500-5300 yr BP (Lauterbach et al., 2014). It may correspond to Bond cycle 4 (Lauterbach et al., 2014).

\section{2 ka event}

This event is weakly marked in the C087 record at $4190-4100-4010 \mathrm{yr}$ BP. With the Picea increase, starts a longer-term charcoal increase. The record of lake Sayram (N Xinjiang) (Lan et al., 2020) shows five phases of enhanced effective moisture, the first one being in the interval of $4000-3780 \mathrm{yr}$ BP. According to the map of Wang et al. (2016), the impact of the 4.2 ka event is so far unknown in Kirghizstan and surroundings and might be equally drier or wetter. It is suggested here that the impact of the 4.2 event, if this is what is recorded, is not drastic: slightly wetter and colder at $4.2 \mathrm{ka}$ and to some extend afterwards.

End of Bronze Age: $3.2 \mathrm{ka}$ and following centuries

In core C087, this period corresponds to zone IK-3 (3.3-2.7 ka) that is $580 \mathrm{yr}$ long. The Picea peaks (around $3.2 \mathrm{ka} \mathrm{BP}$ ) relate to several changes in the pollen record, including an increase of Cyperaceae at 3.2-2.8 ka (possibly Kobresia, an alpine sedge). The latter could be due to an increase of the alpine meadows instead of, for example, local lake margin plants (e.g. as for Swan Lake, Huang et al., 2015). This is followed by a low in Amaranthaceae percentages (2.9 ka). It is noteworthy that this Picea maximum follows pollen zone IK-2 for which a strong ground cover opening is reconstructed in its later part. It really appears therefore as a compelling vegetation recovery. After pollen zone IK-3, the concentrations of microcharcoal and of all coprophilous fungi take a while before recovering. This delay may illustrate a negative impact of the cold and humid episode on local populations.

In zone KA-5 (especially between 3350-2900 yr BP) of Karakol (synchronous to zone IK-3), a clear decline of Picea and a partial replacement by steppe are 
reconstructed (Beer and Tinner, 2008). Combining the results of these two sites from two different altitudes (1607 $\mathrm{m}$ and $2353 \mathrm{~m}$ ) clearly re-inforces the idea of a downward shift of the spruce belt due to climate, rather than a downward increase of its area.

A remarkably synchronous more humid episode has been recognised in Sonkul at 3450-2850 years BP (Lauterbach et al., 2014).

At $2800 \mathrm{yr}$ BP, the end of the Bronze Age is noted in south-central Siberia and the Scythians, who were Iron Age pastoralists, expanded (van Geel et al., 2004). Near Issyk-Kul, a related group of pastoralists, the Saka people left behind some prominent kurgans (Romanovsky, 2002b). From a study of the Talgar River fan (Fig. 1), just north of Issyk-Kul, on the Kazak foothill of the Tien Shan, Chang et al. (2017) proposed that the shift from Bronze Age to Iron Age corresponds to a change from colder - wetter conditions to warmer - drier ones. This correlates well to the changes between pollen zone IK 3 and 2 at $2.8 \mathrm{ka}$ and, amongst other changes, the increase of the semi-desert with Ephedra.

Little Ice Age

Pollen zone IK-5 shows an increase of Picea near Issyk-Kul. It is accompanied by several other minor changes in the diagram, such as a peak in Poaceae (possibly due to human activities and grassland expansion). In core IK98i-28 in Issyk-Kul (Giralt et al., 2004), the Little Ice Age (LIA) is as, in core C087, illustrated by a double peak of Picea.

To the contrary, a clear decrease of the Picea occurs in Karakol (zone KA8) in the top $50 \mathrm{~cm}$ of the sequence (Beer and Tinner, 2008). The ${ }^{14} \mathrm{C}$ date at $53-51$ $\mathrm{cm}$ depth has a large 2 sigma range and may represent up to the last 300 years. However, a human component for the Picea decline cannot be excluded, as suggested by Beer and Tinner (2008). This period, related to the LIA, when combining the Karakol and the Issyk-Kul records shows again a downwards shift of the whole forest belt, upper and lower limits. Further afield, Chen et al. (2006) in Bosten Lake, $700 \mathrm{~km}$ east of Issyk-Kul, at $1048 \mathrm{~m}$ elevation, a multiproxy study shows increased precipitation during the LIA, i.e. AD1500-1900.

In other respects, the Tien Shan glaciers were more extensive during the LIA (Savoskul, 1997; Solomina et al., 2004). Esper et al. (2002) have reconstructed from Juniperus tree rings the temperature over the last 1300 years in western Central Asia. Their results within the LIA (AD1140-1874) indicate that the coldest period appeared to be in the first half of the $17^{\text {th }}$ century. This fits well with the first Picea peak.

Finally, while the Picea values peak at 5.5 and 4.2 ka are not strongly marked, while those before the end of the Bronze Age and in the Little Ice Age are very clear and supported by other changes in the vegetation in Issyk-Kul and regionally.

\subsection{Palaeoclimates}

In the earlier part of the Holocene, the five phases of enhanced effective moisture in Lake Sayram (N Xinjiang) (Jiang et al., 2013; Lan et al., 2019 2020) and the four episodes of enhanced winter precipitation in Sonkul (Lauterbach et al., 2014) were in both cases attributed to the southern migration of the Westerlies driven by negative phase of NAO. Further East, similarly the humid 
phases of Bosten Lake record were attributed the negative anomaly of the NAO (Chen et al., 2006). Temperature reconstructed at the alpine Swan Lake (515 km east of Issyk-Kul, $2541 \mathrm{~m}$ asl) on the southern slopes of the Chinese Tien Shan indicate the intensity of the Eastern Asian monsoon system. Huang et al. (2015) have reconstructed the vegetation by pollen analysis over the last $8.5 \mathrm{ka}$. They found a warmer phase at 5.5-4.5 ka with high lake level, followed by a slightly colder phase at 4.5-2.6 ka. Chen et al. (2019) summarise well the climatic influences on Arid Central Asia.

When the Issyk-Kul sequence is compared to these regional records, it appears that the four periods of Picea expansion fit well with the Holocene precipitation pattern of the region and are clearly forced by the Westerlies.

\section{Conclusions}

The vegetation history of the last 5600 years shows Issyk-Kul surrounded by a dry Artemisia steppe, which became slightly wetter from 4500 to $2700 \mathrm{yr}$ BP (strong reduction of the semi-desert taxon, Ephedra). Comparison to other regional records confirm the same driving force for this part of Arid Central Asia, i.e. the Westerlies and their southward migration.

The representation of the spruce forest belt above the lake has fluctuated several times. Based on the record of Picea pollen grains (percentages and concentration), four climatic periods of more humid and likely cooler climate stand out: $5.5 \mathrm{ka}, 4.2 \mathrm{ka}$ and following centuries, the end of the Bronze Age (3.2 $\mathrm{ka}$ and following centuries) and the Little Ice Age. The latter two are strongest. Using the pollen diagram of Issyk-Kul and a pollen diagram from a lake at higher altitude (Karakol, $750 \mathrm{~m}$ above Issyk-Kul ), it is possible to show that the forest belt temporarily moved down before the end of the Bronze Age and in the Little Ice Age when the climate was wetter and colder, without expanding vertically. More intense human activities, reconstructed especially in Mid and Late Bronze Age and in the last 830 years, show a good fit to the archaeological and historical records. Bronze Age sites not far from the lake are known such as Uch Kurbu and Chap. Issyk-Kul might also have been a well-used welcome stop-over with its warm waters along the ancient Silk Road.

\section{Acknowledgements}

We are grateful to the IMBE palaeoecology laboratory in Aix-en-Provence (France) for treating the palynological samples.

\section{References}

Aizen VB, Aizen EM, Melack JM and Dozier J (1997) Climatic and hydrologic changes in the Tien Shan, Central Asia. Journal of Climate 10: 1393-1404.

Beer R and Tinner W (2008) Four thousand years of vegetation and fire history in the spruce forests of northern Kyrgyzstan (Kungey Alatau, Central Asia). Vegetation History and Archaeobotany 17: 629-638.

Beer R, Tinner W, Carraro G and Grisa E (2007) Pollen representation in surface samples of the Juniperus, Picea and Juglans forest belts of Kyrgyzstan, central Asia. The Holocene 17 (5): 599-611. 
Beer R, Kaiser F, Schmidt K, Ammann B, Carraro G, Grisa E and Tinner W (2008) Vegetation history of the walnut forests in Kyrgyzstan (Central Asia): natural or anthropogenic origin? Quaternary Science Reviews 27: 621-632.

Bennett K (2007) Psimpoll and Pscomb Programs for Plotting and Analysis. Version Psimpoll 4.27. http://chrono.qub.ac.uk/psimpoll/psimpoll.html (accessed 27 May 2020).

Bolch T (2007) Climate change and glacier retreat in northern Tien Shan (Kazakhstan/Kyrgyzstan) using remote sensing data. Global and Planetary Change 56: 1-12.

Boomer I, Wünnemann B, Mackay AW, Austin P, Sorrel P, Reinhardt C, Keyser D, Guichard F and Fontugne M (2009) Advances in understanding the late Holocene history of the Aral Sea region. Quaternary International 194: 7990.

Burgette RJ, Weldon II RJ, Abdrakhmatov KY, Ormukov C, Owen LA and Thompson SC (2017) Timing and process of river and lake terrace formation in the Kyrgyz Tien Shan. Quaternary Science Reviews 159: 1534.

Burr GS, Kuzmin YV, Krivonogov SK, Gusskov SA and Cruz RJ (2019) A history of the modern Aral Sea (Central Asia) since the Late Pleistocene. Quaternary Science Reviews 206: 141-149.

Cai Y, Chiang JCH, Breitenbach SFM, Tan L, Cheng H, Edwards RL and An Z (2017) Holocene moisture changes in western China, Central Asia, inferred from stalagmites. Quaternary Science Reviews 158: 15-28.

Chang C (2017). Inner Asian pastoralism in the Iron Age: the Talgar case, southeastern Kazakhstan. Nomadic Peoples 21: 173-190.

Chen FH, Huang X, Zhang J, Holmes JA and Chen J (2006) Humid Little Ice Age in arid Central Asia documented by Bosten Lake, Xinjiang, China. Science in China Series D: Earth Sciences 49: 1280-1290.

Chen FH, Yu Z, Yang M, Ito E, Wang S, Madsen DB, Huang X, Zhao Y, Sato T, Birks HJB, Boomer I, Chen J, An Ch and Wünnemann B (2008) Holocene moisture evolution in arid central Asia and its out-of-phase relationship with Asian monsoon history. Quaternary Science Reviews 27: 351-364.

Chen FH, Chen JH, Holmes J, Boomer I, Austin P, Gates JB, Wang NL, Brooks SJ and Zhang JW (2010) Moisture changes over the last millennium in arid Central Asia: a review, synthesis and comparison with monsoon region. Quaternary Science Reviews 29: 1055-1068.

Chen FH, Chen JH, Huang W, Chen SQ, Huang XZ, Jin LY, Jia J, Zhang XJ, An CB, Zhang JW, Zhao Y, Yu ZC, Zhang RH, Liu JB, Zhou AF, Feng $S$ (2019) Westerlies Asia and monsoonal Asia: spatiotemporal differences in climate change and possible mechanisms on decadal to sub-orbital timescales. Earth-Science Review 192: 337-354.

Chen H, Chen Y, Li W and Li Z (2019) Quantifying the contributions of snow/glacier meltwater to river runoff in the Tianshan Mountains, Central Asia. Global and Planetary Change 174: 47-57. 
Cheng H, Zhang PZ, Spötl C, Edwards RL, Cai YJ, Zhang DZ, Sang WC, Tan, M, An ZS (2012) The climatic cyclicity in semi-arid - arid central Asia over the past 500,000 years. Geophysical Research Letters 39: L01705. doi: 10.1029/2011GL050202

Chiba T, Endo K, Sugai T, Haraguchi T, Kondo R and Kubota J (2016) Reconstruction of Lake Balkhash levels and precipitation/evaporation changes during the last 2000 years from fossil diatom assemblages. Quaternary International 397: 330-341.

De Batist M, Imbo Y, Vermersch P, Klerkx J, Giralt S, Lignier V, Beck C, Kalugin I and Abdrakhmatov KE (2002) Bathymetry and sedimentary environment of Lake Issyk-Kul, Kyrgyz Republic (Central Asia): a large, high-altitude, tectonic lake. In: Klerkx J and Imanackunov B (eds) Lake Issyk-Kul: its natural environment. NATO Science Series, Kluwer Academic Publishers, Netherlands, Earth and Environmental Sciences 13, pp. 101 - 123.

Dumany Dupuy P. (2016) Bronze Age Central Asia. Oxford handbooks online, _www.oxfordhandbooks.com, Oxford University Press 10.1093/oxfordhb/9780199935413.013.15

Esper J, Schweingruber FH and Winiger M (2002) 1300 years of climatic history for Western Central Asia inferred from tree-rings. The Holocene 12(3): 267-277.

Giralt S, Julià R and Klerkx J (2001) Microbial biscuits of vaterite in Lake IssykKul (Republic of Kyrgyzstan). Journal of Sedimentary Research 71: 430435

Giralt S, Riera S, Klerkx J, Julià R, Lignier V, Beck C, De Batist M and Kalugin I (2002) Recent paleoenvironmental evolution of Lake Issyk-Kul. In: Klerkx $\mathrm{J}$ and Imanackunov B (eds) Lake Issyk-Kul: its natural environment. NATO Science Series, Kluwer Academic Publishers, Netherlands, Earth and Environmental Sciences 13, pp. 125 - 145.

Giralt S, Julià R, Klerkx J, Riera S, Leroy S, Buchaca T, Catalan J, De Batist M, Beck C, Bobrov V, Gavshin V., Kalugin I., Sukhorukov F., Brennwald M., Kipfer R., Peeters F., Lombardi S., Matychenkov V., Romanovsky V., Podsetchine $V$ and Voltattorni N (2004) 1,000 year environmental history of Lake Issyk-Kul. in: Nihoul J, Zavialov P and Micklin P (eds) Dying and Dead Seas, climatic versus anthropic causes NATO ASI Series, Kluwer Academic publishers. 36, pp. 253-285.

Gómez-Paccard M, Larrasoaña JC, Giralt S and Roberts AP (2012) First paleomagnetic results of mid- to late Holocene sediments from Lake Issyk-Kul (Kyrgyzstan): Implications for paleosecular variation in central Asia. Geochemistry, Geophysics, Geosystem, 13, Q03019, doi:10.1029/2011GC004015,.

Heinecke L, Fletcher WJ, Mischke S, Tian F and Herzschuh U (2028) Vegetation change in the eastern Pamir Mountains, Tajikistan, inferred from Lake Karakul pollen spectra of the last 28 kyr. Palaeogeography, Palaeoclimatology, Palaeoecology 511: 232-242.

Hermes TR, Frachetti MD, Voyakin D, Yerlomaeva AS, Beisenov AZ, Doumani Dupuy PN et al. (2020) High mitochondrial diversity of domesticated goats 
persisted among Bronze and Iron Age pastoralists in the Inner Asian Mountain Corridor. PLOS ONE 15(5): e0233333

Herrera RJ and Garcia-Bertrand R (2018) The Silk Roads. In: Herrera RJ, Garcia-Bertrand R (eds). Ancestral DNA, human origins, and migrations. Academic Press, London, pp. 511-557.

Huang X, Chen Ch, Jia W, An Ch, Zhou A, Zhang J, Jin M, Xia D, Chen F and Grimm EE (2015) Vegetation and climate history reconstructed from an alpine lake in central Tienshan Mountains since $8.5 \mathrm{ka} \mathrm{BP}$. Palaeogeography, Palaeoclimatology, Palaeoecology 432: 36-48.

Huang X, Zhang J, Storozum M, Liu S, Gill J, Xiang L, Ren X, Wang J, Quang M, Chen F and Grimm EC (2020) Long-term herbivore population dynamics in the northeastern Qinghai-Tibetan Plateau and its implications for early human impacts. Rev Palaeobot Palyn 275: 104171.

Huo Y, Gou X, Liu W, Li J, Zhang F and Fang K (2017) Climate-growth relationships of Schrenk spruce (Picea schrenkiana) along an altitudinal gradient in the western Tianshan mountains, northwest China. Trees 31: 429-439.

Jia PW, Betts A, Cong D, Jia X and Doumani Dupuy P (2017) Adunqiaolu: new evidence for the Andronovo in Xinjiang, China. Antiquity 91: 357, 621-639.

Jiang QF, Ji JF, Shen J, Matsumoto R, Tong GB, Qian P, Ren XM and Yan DZ (2013) Holocene vegetational and climatic variation in westerly dominated areas of Central Asia inferred from the Sayram Lake in northern Xinjiang, China. Earth Sciences 56(3): 339-353.

Kaser G, Großhauser M and Marzeion B (2010) Contribution potential of glaciers to water availability in different climate regimes. PNAS 23: 20223-20227.

Klinge M, Bohner J and Erasmi S (2015) Modeling forest lines and forest distribution patterns with remote-sensing data in a mountainous region of semiarid central Asia. Biogeosciences 12: 2893-2905.

Koppes M, Gillespie AR, Burke RM, Thompson SC and Stone J (2008) Late Quaternary glaciation in the Kyrgyz Tien Shan. Quaternary Science Reviews 27: 846-866.

Kulenbekov Z and Merkel BJ (2012) Investigation of the natural uranium content in the Issyk-Kul Lake, Kyrgyzstan. Freiberg Online Geology 33: 3-45. http://tu-freiberg.de/sites/default/files/media/institut-fuer-geologie-718/pdf/ fog_volume_33_0.pdf (accessed 19 March 2020.

Lan J, Xu H, Sheng E, Yu K, Wu H, Zhou K, Yan D, Ye Y and Wang T (2018) Climate changes reconstructed from a glacial lake in High Central Asia over the past two millennia. Quaternary International 487: 43-53.

Lan J, Xu H, Yu K, Sheng E, Zhou K, Wang T, Ye Y, Yan D, Wu H, Cheng P, Abuliezi W and Tan, L (2019) Late Holocene hydroclimatic variations and possible forcing mechanisms over the eastern Central Asia. Sci. China Earth Sci. 62: 1288-1301.

Lan J, Zhang J, Cheng P, Ma X, Ai L, Chawchai S, Zhou K, Wang T, Yu K, Sheng E, Kang S, Zang J, Yan D, Wang Y, Tan L and Xu H (2020) Late Holocene hydroclimatic variation in central Asia and its response to mid- 
latitude Westerlies and solar irradiance. Quaternary Science Reviews 238: 106330

Larrasoaña JC, Gómez-Paccard M, Giralt S and Roberts AP (2011) Rapid locking of tectonic magnetic fabrics in weakly deformed mudrocks, Tectonophysics 507: 16-25.

Lauterbach S, Witt R, Plessen B, Dulski P, Prasad S, Mingram J, Gleixner G, Hettler-Riedel S, Stebich M, Schnetger B, Schwalb A and Schwartz A (2014) Climatic imprint of the mid-latitude Westerlies in the Central Tian Shan of Kyrgyzstan and teleconnections to North Atlantic climate variability during the last 6000 years. The Holocene 24(8): 970-984.

Leroy SAG, López-Merino L and Kozina N (2019) Caspian deep-water dinocyst records show a reversed meridional water gradient at $8.5-4.0 \mathrm{cal}$. ka BP. Quaternary Science Reviews 209: 1-12

Lhuillier J, no date. http://www.gis-reseau-asie.org/fr/johanna-lhuillier-la-periodede-transition-entre-lage-du-bronze-et-lage-du-fer-en-asie-centrale-le. (accessed 27 May 2020).

Li Y, Zhang Y, Zhang, X, Ye W, Xu L., Han Q, Li Y, Liu H and Peng S (2020) A continuous simulation of Holocene effective moisture change represented by variability of virtual lake level in East and Central Asia. Science China Earth Sciences 63

Luneau E, Martinez Ferreras V, Abdykanova A, Tabaldiev K and Motuzaite Matuzeviciute G (2020) The first combined archaeological and archaeometric analyses on Bronze Age pottery from Kyrgyzstan (Uch Kurbu site). Journal of Archaeological Science: Reports 31: 102302

Mathis M, Sorrel P, Klotz S, Huang XT and Oberhänsli H (2014) Regional vegetation patterns at Lake Sonkul reveals Holocene climatic variability in central Tien Shan. Quaternary Science Reviews 89: 169-185.

Motuzaite Matuzeviciute G, Hermes TR, Mir-Makhamad B and Tabaldiev K (2020) Southwest Asian cereal crops facilitated high elevation agriculture in the central Tien Shan during the mid-third millennium BCE. PLOS ONE 15(5): e0229372.

Motuzaite Matuzeviciute G, Preece RC, Wang S, Colominas L, Ohnuma K, Kume S, Abdykanova S and Jones MK (2017) Ecology and subsistence at the Mesolithic and Bronze Age site of Aigyrzhal-2, Naryn valley, Kyrgyzstan. Quaternary International 437: 35-49.

Motuzaite Matuzeviciute G, Tabaldiev K, Hermes T, Ananyevskaya E, Grikpedis $M$, Luneau $E$ et al. (2020) High-altitude agro-pastoralism in the Kyrgyz Tien Shan: New excavations of the Chap farmstead (1065-825 cal b.c.). Journal of Field Archaeology 45: 29-45.

Narama C, Kääb A, Duishonakunov M and Abdrakhmatov K (2010) Spatial variability of recent glacier area changes in the Tien Shan Mountains, Central Asia, using Corona ( 1970), Landsat ( 2000), and ALOS ( 2007) satellite data. Global and Planetary Change 71: 42-54.

National Geographic (2012) 2012 Issyk Kul expedition: Search for a sunken palace. http://voices.nationalgeographic.com/2012/09/06/2012-issyk-kulexpedition-search-for-a-sunken-palace/ (accessed 27 May 2020). 
Pan Y, Yan S, Behling H and Mu G (2013) Transport of airborne Picea schrenkiana pollen on the northern slope of the Tianshan Mountains (Xianjiang, China) and its implications for paleoenvironmental reconstruction. Aerobiologia 29: 161-173.

Parzinger H (2008) The 'Silk Roads' concept reconsidered: About transfers, transportation and transcontinental interactions in prehistory. The Silk Road 5 (2): 7-15.

Pieczonka T and Bolch T (2015) Region-wide glacier mass budgets and area changes for the Central Tien Shan between 1999 using Hexagon KH-9 imagery. Global and Planetary Change 128: 1-13.

Ramsar (2013) The Issyk-kul state nature reserve with the Issyk-kul Lake https://rsis.ramsar.org/fr/ris/1231 (accessed 28 May 2020).

Rasmussen KA, Ricketts RD, Johnson TC, Romanovskyy VV and Grigina OM (2001) An 8,000 Year Multi-proxy record from Lake Issyk-Kul, Kyrgyzstan. PAGES Newsletter 9(2): 5-6.

Ricketts RD, Johnson TC, Brown ET, Rasmussen KA and Romanovsky VV (2001) The Holocene paleolimnology of Lake Issyk-Kul, Kyrgyzstan: trace element and stable isotope composition of ostracodes, Palaeogeography, Palaeoclimatology Palaeoecology 176: 207-227.

Romanovsky VV (2002a) Hydrobiology of Lake Issyk-Kul. In: Klerkx J and Imanackunov B (eds). Lake Issyk-Kul: its natural environment. NATO Science Series, Kluwer Academic Publishers, Netherlands, Earth and Environmental Sciences 13, pp. 27-43.

Romanovsky VV (2002b) Water level variations and water balance of Lake IssykKul. In: Klerkx J and Imanackunov B (eds). Lake Issyk-Kul: its natural environment. NATO Science Series, Kluwer Academic Publishers, Netherlands, Earth and Environmental Sciences 13, pp. 45 - 58.

Romanovsky VV, Tashbaeva S, Crétaux J-F, Calmant S and Drolon V (2013) The closed Lake Issyk-Kul as an indicator of global warming in Tien-Shan. Natural Science 5(5): 608-623.

Salamat A, Abuduwaili J and Shaidyldaeva N (2014) Impact of climate change on water level fluctuation of Issyk-Kul Lake. Arab Journal of Geosciences 8: 5361-5371.

Savoskul OS (1997) Modern and Little Ice Age glaciers in "humid" and "arid" areas of the Tien Shan, Central Asia: two different patterns of fluctuation. Annals of Glaciology 24: 142-147.

Savvaitova K and Petr T (1992) Lake Issyk-kul, Kirgizia. International Journal of Salt Lake Research 1: 21-46.

Solomina O, Barry R and Bodnya M (2004) The retreat of Tien Shan glaciers (Kyrgyzstan) since the Little Ice Age estimated from aerial photographs, lichenometric and historical data. Geografiska Annaler. Series A, Physical Geography 86 (2): 205-215.

Sorg A, Bolch T, Stoffel M, Solomina O and Beniston M (2012) Climate change impacts on glaciers and runoff in Tien Shan (Central Asia). Nature Climate Change 2: 725-731. 
Stuiver M, Reimer PJ and Reimer RW (2020) CALIB 7.1 [WWW program] at http://calib.org (accessed 21 March 2020).

Thompson SC, Weldon RJ, Rubin CM, Abdrakhmatov K, Molnar P and Berger GW (2002) Late Quaternary slip rates across the central Tien Shan, Kyrgyzstan, central Asia. Journal of Geophysical Research 107: 2203, doi:10.1029/2001JB000596.

UNESCO (2017) Silk Roads sites in Kyrgyzstan http://whc.unesco.org/en/tentativelists/5518/ (accessed 17 March 2020).

University of Central Asia (2018) 2009 Map of forest location in the KR.jpeg. http://msri-hub.ucentralasia.org/node/3540 (accessed 29 January 2020).

van Geel B, Bokovenko NA, Burova ND, Chugunov KV, Dergachev VA, Dirksen VG, Kulkova M, Nagler A, Parzinger H and van der Plicht J (2004) Climate change and the expansion of the Scythian culture after $850 \mathrm{BC}$ : a hypothesis. Journal of Archaeological Science 31: 1735-1742.

Walter H and Box EO (1983) The orobiomes of Middle Asia. In: West NE (ed) Ecosystems of the world: temperate deserts and semi-deserts. Elsevier scientific publishing company, Amsterdam pp. 161 - 191.

Wang J, Sun L, Chen L, Xu L, Wang Y and Wang X (2016) The abrupt climate change near 4,400 yr BP on the cultural transition in Yuchisi, China and its global linkage. Nature Scientific Reports 6: 27723.

Wei HC, Hou GL, Fan QS, Madsen DB, Qin ZJ, Du YS, Sun YJ, Gao JY and Shan FS (2020) Using coprophilous fungi to reconstruct the history of pastoralism in the Qinghai Lake Basin, Northeastern Qinghai-Tibetan Plateau. Prog. Phys. Geogr. 44(1): 70-93.

Wu G, Liu X, Chen T, Xu G, Wang W, Zeng X and Zhang X (2015) Elevationdependent variations of tree growth and intrinsic water-use efficiency in Schrenk spruce (Picea schrenkiana) in the western Tianshan Mountains, China. Frontiers in Plant Science 6(309): 1-12.

Yan D, Xu H, Lan J, Zhou K, Ye Y, Zhang J, An Z and Yeager KM (2019) Solar activity and the westerlies dominate decadal hydroclimatic changes over arid Central Asia. Global and Planetary Change 173: 53-60.

Zhang Y, Kong Z and Zhang H (2013) Multivariate analysis of modern and fossil pollen data from the central Tianshan Mountains, Xinjiang, NW China. Climatic Change 120: 945-957.

\section{Captions}

Figure 1: Map of central Asia with sites mentioned in the lake. B: Bosten Lake, K: Karakol, Sa: Sayram Lake, So: Sonkul, Sw: Swan Lake, T: Talgar River fan. Inset: Issyk-Kul with core C087 (red dot) and the Bronze Age site of Uch Kurbu (black square). Core C142a is comprised within the red dot of core C087.

Figure 2: Sediment log (according to Larrasoaña et al. (2011) and GomezPaccard et al. (2012)), dating (updated from Larrasoaña et al. (2011) and Gomez-Paccard et al. (2012)) and pollen zones of core C087. 
Figure $3 \mathrm{a}, \mathrm{b}, \mathrm{c}$ and $\mathrm{d}$ : Pollen diagram of core C087 in percentages plotted on calibrated radiocarbon ages. 10x exaggeration curves and black dots for values lower than $0.5 \%$. Sum without Artemisia used for percentages.

Figure 4: Picea peaks in percentages (on a sum without Artemisia) and concentration in palynomorphs per $\mathrm{ml}$ of wet sediment from core C087 with corresponding dates. Archaeological chronology for north central Asia according to Dumany Dupuy (2016). Horizontal grey boxes for the four Picea peaks (>18\% and $>1500 \mathrm{pollen} / \mathrm{ml}$ ), vertical orange boxes for human impact, light blue box for wetter period.

Table 1: Radiocarbon dates updated from Larrasoaña et al. (2011) and GomezPaccard et al. (2012) and calibration for core C087 with Calib 7.1 and INTCAL13. *: for rejected date. 


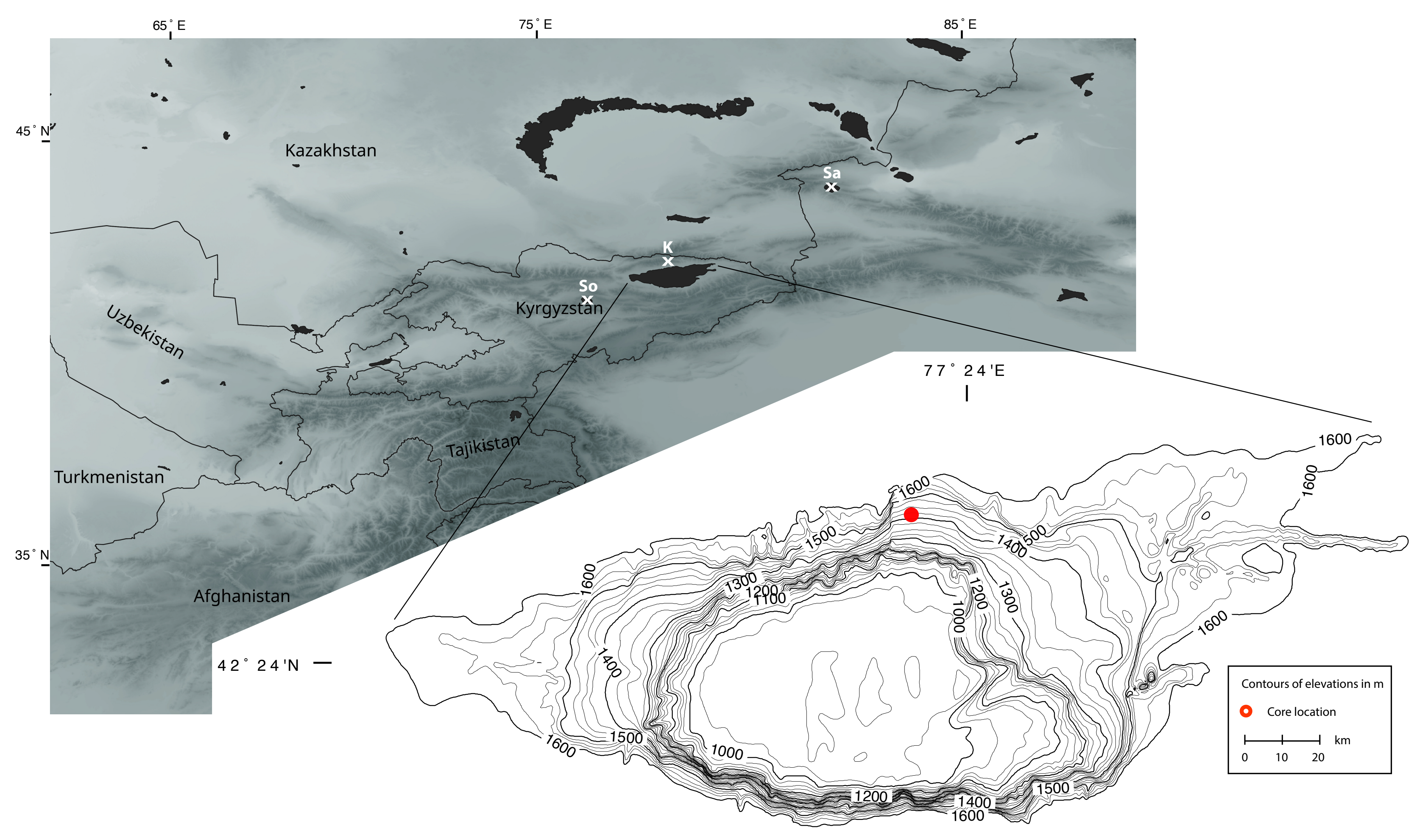




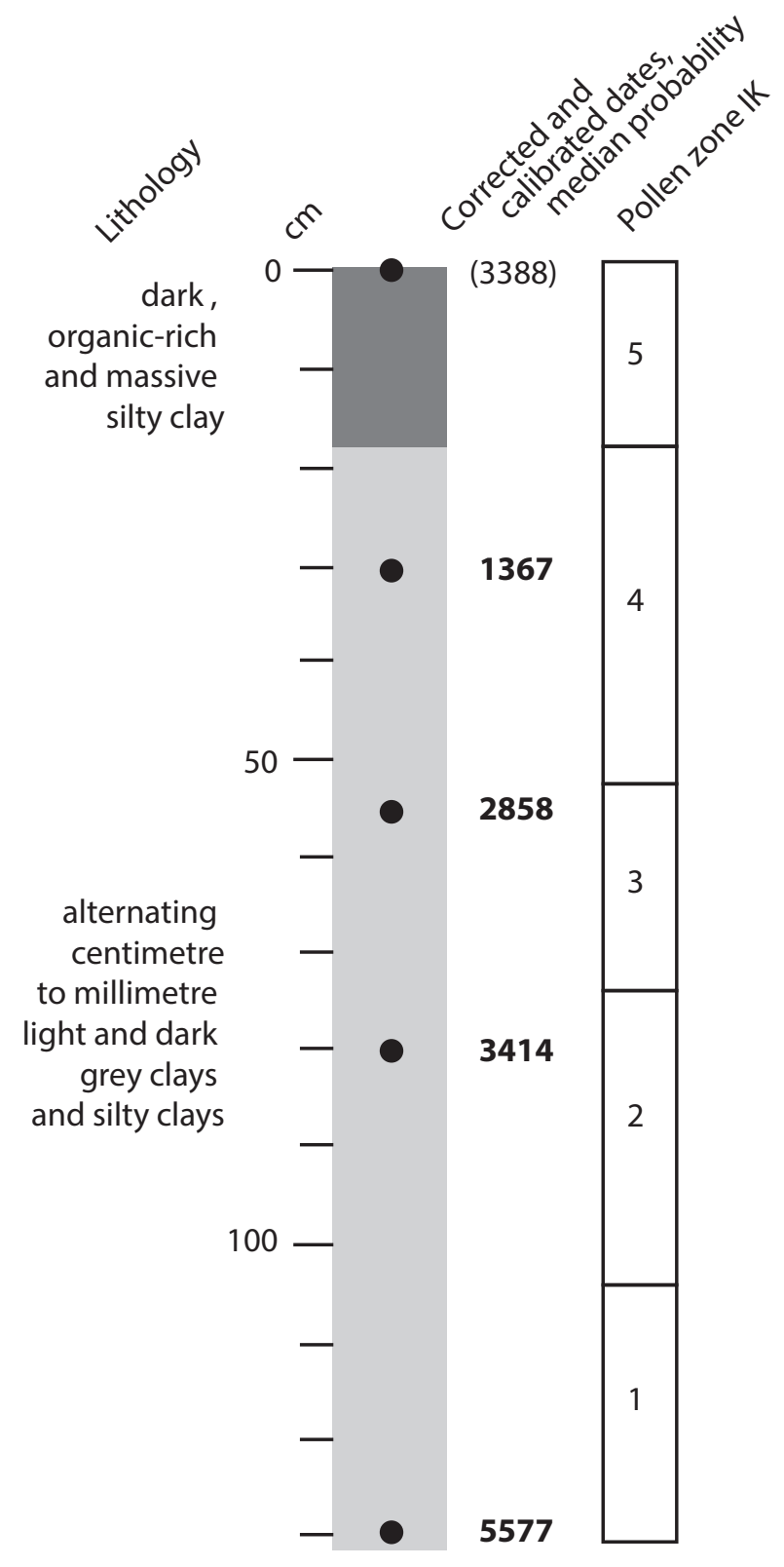


Issyk-Kul, core C087, palynology, chronology, Artemisia out of sum Analyses: S. Leroy

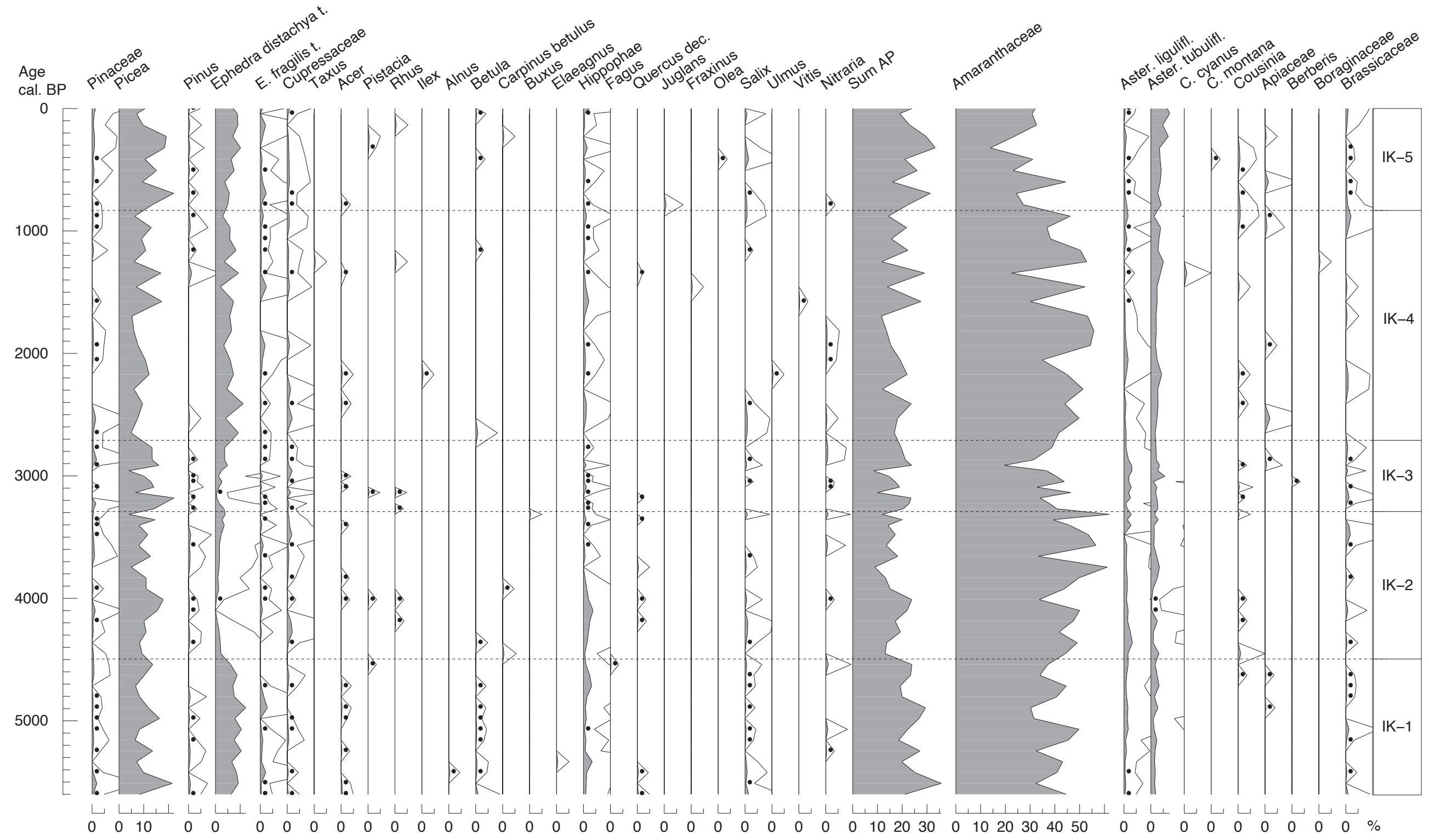


Issyk-Kul, core C087, palynology, chronology, Artemisia out of sum Analyses: S. Leroy

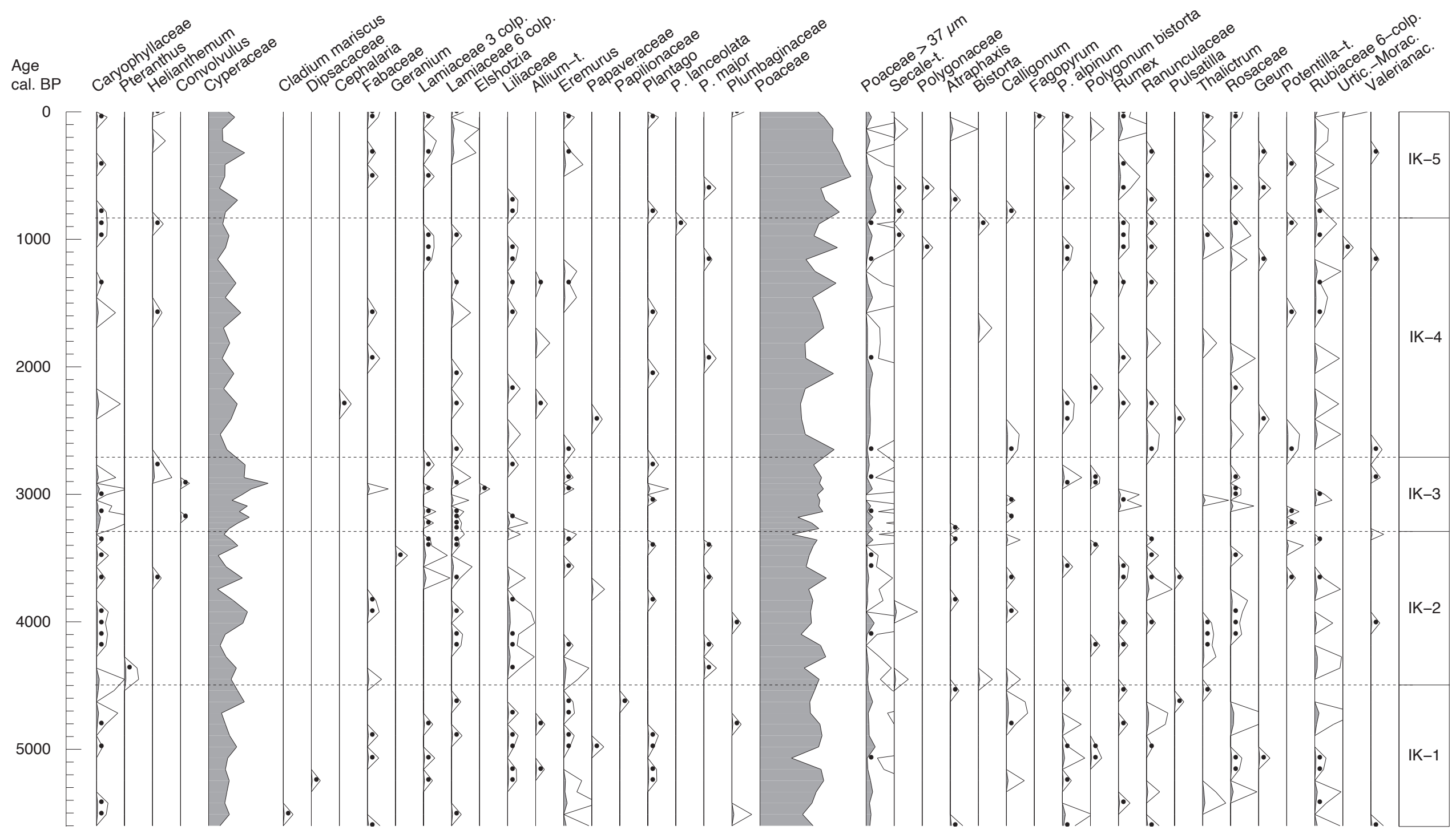

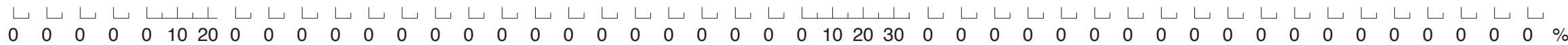


Issyk-Kul, core C087, palynology, chronology, Artemisia out of sum Analyses: s. Leroy

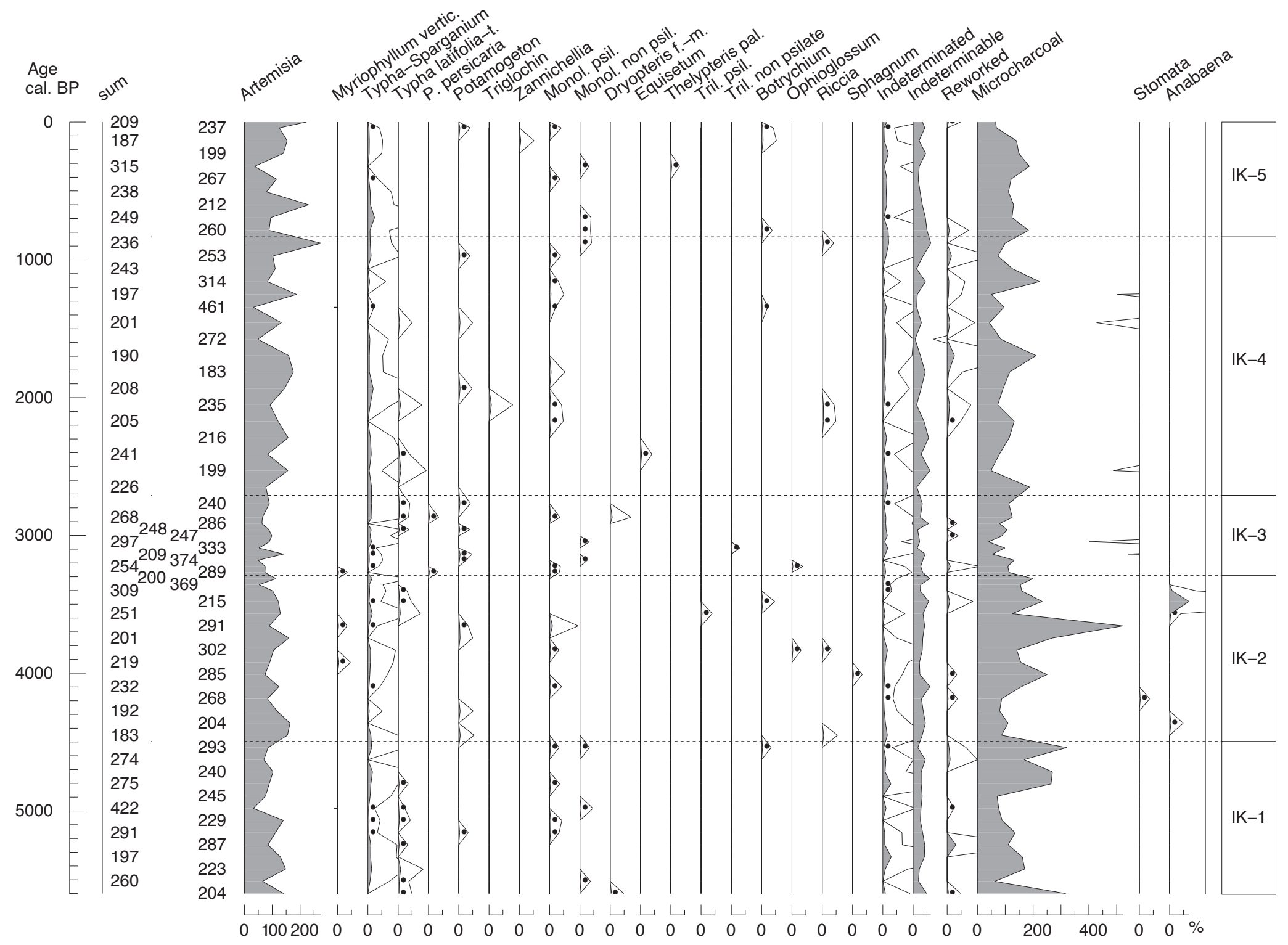


Issyk-Kul, core C087, palynology, chronology, Artemisia out of sum Analyses: S. Leroy

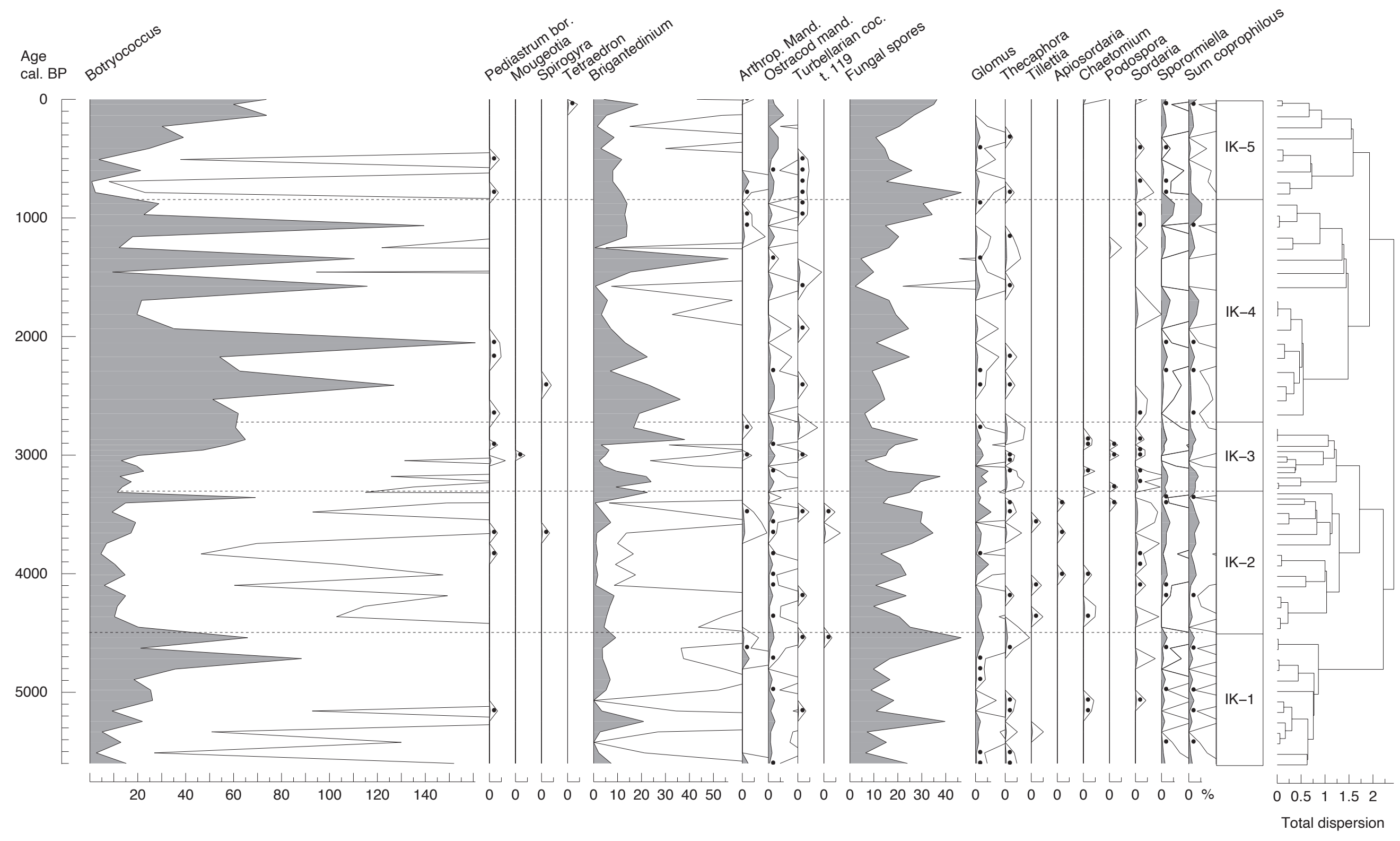




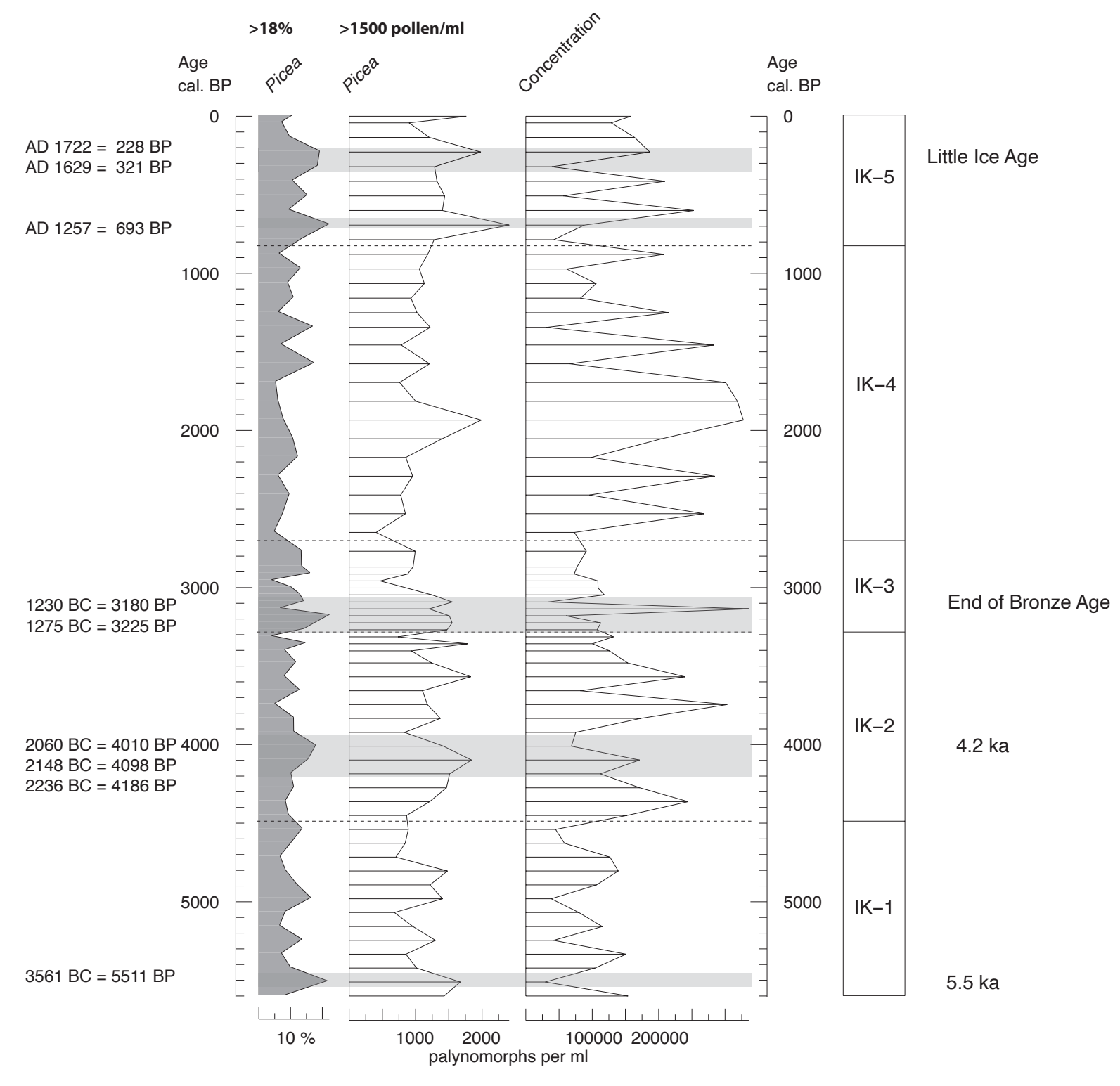

